\title{
Innovative Approaches in Distance Education in the Field of Environmental Management and Environmental Technologies
}

\author{
Mikhail Leontev ${ }^{1, *}$ \\ ${ }^{1}$ Moscow State University of Civil Engineering, 129337 Yaroslavskoe sh. 26, Moscow, Russia
}

\begin{abstract}
This article discusses the innovative structures and components of distance learning and education, discusses the results of application of approaches to teaching in the electronic environment based on the proposed andragogic and pedagogical models of teaching in cyberspace, for adult learners, bachelor graduates of "Management" for the training program "Introduction to environmental management systems". This program particularly addresses the role of environmental managers in a company activity, the implementation of ecologically clean technologies. The author proposed an innovative nonlinear andragogic model of learning. The model was mediated by the constructive approach and problem-oriented learning.
\end{abstract}

\section{Introduction}

Turning to adult education, which occurred in the past two decades, linked to labor market requirements, increasing demand for the competence and professionalism of staff $[1,2]$. The need for adult education, including the training of environmental managers, due to the social, scientific and technological progress of society, changes in the content and nature of work, the creation and implementation of new technologies [3].

The current situation requires a finding of a balance between ecology and economics [4]. Find that balance is intended to environmental management [5], it is a new direction of the organizational management. These circumstances lead to an increasing demand for specialists in the field of environmental management, retraining, further training and acquire new skills, often through distance learning, as many experts are often uncompetitive $[6,7]$.

The role of environmental managers in the enterprise activities is determined by the extent of the impact of the enterprise on the environment and the level of their social responsibility. In addition to developing environmental management policies, the specialist is actively involved in the manufacturing process, oversees compliance with the applicable standards of production technology, developing the manuals on environmental safety of the company, instructs staff on environmental safety.

\footnotetext{
Corresponding author: miillen@rambler.ru
} 
In view of such a wide-scale problems, modern environmental managers should meet strict professional requirements, also requirements to personal qualities. Personal qualities of environmental managers are the basis for the formation and development of professional qualities. They allow to act within the law and comply with the basic principles of environmental audit. The environmental manager should be: 1) honest: truthful, sincere, restrained; 2) open to be able to accept alternative ideas or points of view; 3) diplomacy, able to interact tactfully with people; 4) supervisory, actively acquainted with the surroundings and activities; 5) insightful, intuitively assess the situations; 6) versatile, to be ready to different situations; 7) resistant, persistent, focused on achieving objectives; 8) able to make timely decisions based on logical reasons and analysis; 9) independent, be able to act and perform their functions independently, at the same time, effectively cooperate with colleagues [8].

Training of environmental managers often follow the way of discovery in Russian universities new master's degree programs based on undergraduate, using innovative approaches and methods, using problem-based learning and andragogic approach.

The program "Introduction to environmental management systems" involves the study of international experience in the application of environmental management systems in order ecologization of manufacturing processes and clean production output; organizing the preparation, planning and implementation of environmental management systems in the enterprises; assess the effectiveness, efficacy and impact of activities in the field of environmental management with environmental auditing procedure, the study of experience of application of environmentally friendly technologies as a means of sustainable development. The use of environmentally friendly technologies allows to ensure the protection of the environment, less pollution, reasonable use of resources, while recycling lends itself to a large part of the wastes and products, and all residual contaminants are recycled more acceptable manner to the environment compared with replaceable technologies. The development of the program involves the use of problem-based learning and andragogic approach.

\section{Literature review}

Problem-based learning is a pedagogical strategy, a special style of comprehending knowledge in which it becomes possible the complete mastery of the problem with deep, active, persistent, contextual learning in real-life contexts with maximum use of substantiated information resources. Thus, the role of the teacher in problem-based learning is to promote active discussion of a problem, providing a complementary work of learners, their active cooperation, usually in quantitatively small groups, providing the possibility of obtaining required information [9]. The teacher can play the role of an expert on the discussing problem, a head on the use of information sources and a consultant in performing group tasks, and the volume of direct imperative instructions is minimized [10].

Andragogic approach covers various areas of education, it was developed through continuing education as a new paradigm, which involves a rethinking of the concept of education, its aims, essence, principles, functions, modes of organization [11]. Modern teachers use the principles of the andragogic approach fully or partially in various conditions. Based on his own observations M. Knowles put forward five points that reflect his concept of andragogy. Adult learners: 1) are taking control of their learning; 2) bring a wealth of personal experience in educational institutions; 3 ) begin training, being motivated to it; 4) focused on solving problems in the learning process; 5) especially sensitive to factors of intrinsic motivation [12].

These provisions contrast sharply with the provisions of traditional pedagogy, where learners are dependent personalities who bring little experience (or not bring) in learning 
activities, motivation to learn is mainly external, for example, from parents, teachers, or connected with the threat of punishment. In the practice and theory of modern education there are studies showing different conditions of formation of educational motivation, including professional orientation of the personality of the future ecological managers [13]. Therefore, it is necessary to explain the essence of learning and to associate the logic of the academic discipline with personal needs of students [14].

The provisions of andragogics are applicable for e-learning environment. They should be used for conducting online courses by teachers, facilitation, to understand the needs of adult learners and to strengthen the collaborative distance learning environment. Today, teachers of online courses need to know your audience and understand its requirements, characteristics and expectations $[15 ; 16]$. Online courses must be carefully structured to provide flexibility of learning and understanding by learners of course objectives and tasks, to facilitate the exchange of experience between learners, for example, by using group projects and interactive discussions, thereby increasing the value of the course for participants [17; 18].

Teachers should provide time in order to the relationships between learners were developed based on modeling positive examples of joint activities. In addition, the course content must also have the opportunity to develop, in contrast to the rigidly prescribed regulations [19].

Distance learning involves interaction between the teacher and learners at a distance, while retaining all the inherent components of the educational process (objectives, content, organizational forms, methods, means of learning). Distance learning is being implemented specific innovative means of information technologies involving interactive communication.

Models of organization of educational process using distance educational technologies can also be classified on the basis of three parameters, proposed by V. E. Bochkov: 1) the degree of activity of pedagogical interaction of a teacher and learner in the implementation of the educational process; 2) the degree of integration of theoretical learning on a specific educational program with practical professional activity of a learner in relevant field; 3 ) the degree of organizational and methodological support and control of independent work of a learner from the educational institution [20].

Distance learning requires the application of learning strategies that differ from traditional teaching in a classroom, the teacher should be ready to provide support to learners for better assimilation rate. In addition to these widely recognized educational strategies, such as constructivist approach [21] and the model of problem-based education [22], andragogic approach to e-learning is highly effective among adult learners.

The basis of interaction between teachers and learners in distance environment is the assimilation of all participants of educational process the innovative educational actions as active and interactive learning technologies both in a classroom, and in distance learning have the same methods of organizing active process of learning. New learning technologies help the modeling new experience by the specialists, the formation of necessary knowledge, abilities and skills, professional attitudes and views.

The condition of training learners for collaboration in active educational environment is the ability of teachers who organize distance learning to create the environment. The cooperation of learners requires to create the safe environment in which they are not afraid to share ideas, experiences and to learn through conversations and information exchange.

It should be understood that every learner is included in the distance learning environment for the specific reason, whether personal desire to learn something new or the relevance of the course by the employer or institution [23]. If learners are unclear about specific goals and objectives of the course, the facilitator should take steps to help learners to identify their learning needs. Facilitator as the organizer of the training should be ready 
to provide assistance to learners. The learners determines learning needs through discussion with the facilitator the reasons at which the learner took the course, and by questioning (interviewing) learners about expectations from the study of this course. Learner's needs [24] are in the center of teaching, and a variety of learning resources should be available. Learners know about these resources in the course syllabus and the course lecturer directs the learners through the channels of Internet communications if necessary.

\section{Research objectives}

The aim of this study was to identify and describe the methods preferred by distance learning teachers from the point of view of adult learners, graduates at the bachelor's 38.03.02 "Management", which passed training under the program "Introduction to environmental management systems" in 2015. The development of the program and training course based on it was conducted on the basis of the system and activities approaches. The content of the curriculum meets the requirements of Federal state educational standard of the third generation.

\section{Methods}

The survey was used for data collection. It was used a modified technique of G. Conti [25], designed to detect the use of the principles of andragogics (personality centered learning) in all forms of teaching, including training adults in cyberspace. This technique is also designed to determine the key pedagogical approaches to education.

It was used a Likert scale from zero to five for assessment of responses, with 5 the highest score (support approach that matches the name of the factor) and 0 the minimal score (support the opposite approach). The reliability coefficient Cronbach alpha for the technique was $0,91(\mathrm{~N}=78)$.

It was applied a factor analysis which allowed to identify seven factors, carrying to the teaching: 1) personally-oriented activities, 2) personal instruction to learners, 3) the use of experiment in teaching, 4) assessment of learners' needs, 5) the involvement of learners in the educational process, 6) flexibility in the personal development, 7) creation of a favorable psychological climate. The seven factors include main elements that describe the pedagogical activity in general. High scores for factors provide support for the concept implied in the title of factors. Low scores provide support for the opposite concept.

\section{Results}

The results of the study demonstrated that 78 interviewed adult learners, which took the distance learning program "Introduction to environmental management systems", believe that their teachers in the distance environment are mainly supported centered on a teacher (pedagogical) approach to teaching in cyberspace, although adult learners thought that teachers adhere to personal centered (andragogic) approach to teaching in some situations.

Table 1 presents the results of analysis for each of the seven factors of methods of the study. Given the average values for the sample across all seven factors, each was covered by several questions. The Table 1 also includes standard deviations. 
Table 1. Standard deviations

\begin{tabular}{|l|l|l|}
\hline Factors & $\mathrm{M}$ & $\mathrm{SD}$ \\
\hline 1. Activities centered on learner & 2.54 & 1.12 \\
\hline 2. Personalized approach to learning & 2.49 & 0.93 \\
\hline 3. The use of experiment in teaching & 3.31 & 0.92 \\
\hline $\begin{array}{l}\text { 4. Assessment of learners' needs } \\
\text { process }\end{array}$ & 2.97 & 0.98 \\
\hline $\begin{array}{l}\text { 6. Flexibility in personality development } \\
\text { psychological climate }\end{array}$ & 2.11 & 1.07 \\
\hline
\end{tabular}

The data in the table show that the teachers in the distance environment have attributed low scores for items relating to four of the seven factors. Low scores are marked according to factors such as activities centered on learner, personalized approach to learning, the involvement of learners in the learning process, flexibility in personality development. High scores were marked on the following factors: the use of experiment in teaching, assessment of learners' needs, the creation of a favorable psychological climate.

These results show that although teaching in the online environment was implemented to some extent in providing andragogic manner, for example, took place the connection of knowledge with experience, assessing learners' needs and creating a favorable psychological climate, teaching methods are not centered on learners or to promote the activities focused on learners. The data for the factor 6 indicate that the teachers did not support the cooperation of learners in the learning process, considered themselves as providers of knowledge rather than facilitators. They never used such modern educational approaches, as the negotiations for curriculum and priority learning areas with learners or educational contract. First of all, teachers in distance environment has approved the rigidity and lack of sensitivity to the personal needs, valued memorization as the main teaching technique.

It was built the linear model according to the results of analysis of adult learners' perception of teaching strategies in distance environment. Adult learners faced the teaching strategies when they trained under the program "Introduction to environmental management systems". You can clearly understand that this pedagogical model is not conducive to adult learning in cyberspace.

Adult learners begin to learning remotely and face: 1) the dominant role of teachers; 2) a predominance of knowledge transmission; 3) teaching for the sake of passing tests, quizzes and examinations; 4) ignoring of the personal characteristics of adult learners; 5) teaching orientation on the achievement of formal indicators, unmanifested desire of teachers to develop capabilities and competences of learners.

In terms of pedagogical approach, teachers are inclined toward formal testing, relying more on standardized tests than on informal methods of assessment. First of all, teachers saw themselves as providers of knowledge, rather than facilitators. They emphasize the importance of mastering of knowledge and, as a rule, one basic practice teaching method. They believe that memorization can facilitate greater autonomy of thinking, are in favor of 
the lecture method and the dominance of a teacher in a classroom. Pedagogical approach does not encourage the search for examples and perform tasks related to real life situations, the desire to relate course content to everyday life. The teachers are not attracted to their adult learners to develop meaningful performance criteria to assess performance, planning activities, not negotiate the priorities of the curriculum with the learners or use of educational contracts. The teachers believe that well disciplined audience is the stimulus for learning.

\section{Conclusion}

According to the results it can be concluded that teachers in the distance environment did not consider adult learners as the adults, used mainly pedagogical methods that work well in education and training children. Such methods lead learners to achieve certain indicators and the low level of skills and competences.

At the same time, the author offers an innovative non-linear andragogic learning model. The model is mediated of constructive approach and problem-based learning.

Adult learners go to study, and in the learning process following factors take place: 1) negotiations on the curriculum with the learners; 2) educational contracts; 3) non-formal methods of assessment; 4) accounting and integration into learning process of the characteristics of adult learners; 5) the teaching centered on the development of abilities and personal transformation.

In particular, teachers, applying andragogic approach, plan learning activities, taking into account the previous experience of the learners, calling learners to link new knowledge with prior experience. They strive to ensure that each learner has found what he wanted, based on individual meetings and informal counseling. They also diagnose the gap between the learner's goals and current performance levels. Teachers establish a friendly and informal atmosphere, as a first step towards the andragogic model. There is the removal of barriers, it is used multiple competences as building blocks for educational objectives and the personal transformation [26]. Teachers urged to take risks and perceive mistakes like a natural part of the learning process, look at failures as the feedback channels.

Democratic approaches to teaching are based on the andragogic model. Andragogic methods take into account the interests and experiences of adult learners. Characteristics of mature person of adult learner are taken into account in the learning process, with adult learners are not treated like children. This model better meets the challenges of adult learning in distance environments than pedagogical one, in particular, the objectives of training under the program "Introduction to Environmental Management Systems". The final result of the andragogic model is the transformation and personal development. The choice of pedagogical or andragogic model by teachers depends on the specific social contexts, educational philosophy, the influence of culture and administrative preferences.

\section{References}

1. A.D. Ishkov, Procedia - Social and Behavioral Sciences, 142, 54-58 (2014)

2. I.A. Kalinina, T.N. Magera, Ekonomika i predprinimatel'stvo, 3(2), 441-446 (2015)

3. E. Shnyrenkov, I. Pryadko, Procedia Engineering, 117, 330-335 (2015)

4. I.P. Pryadko, International Journal of Applied Engineering Research, 10(21), 4214742152 (2015)

5. N.G. Miloradova, A.D. Ishkov, Procedia Engineering, 117, 246 (2015)

6. M.S. Knowles, The Adult Learner: A Neglected Species (3rd Ed.) (Gulf Publishing, Houston, 1984) 
7. Z.I. Ivanova, O.V. Yudenkova, A.D. Ishkov, E.A. Shnyrenkov, International Education Studies, 8(5), 232-239 (2015)

8. A.V. Anisimov, Ekologicheskiy menedzhment (Feniks, Rostov-on-Don, 2009)

9. G. LloydJones, D. Margetson, J.G., Medical Education, 32, 492-494 (1998)

10. D.T.A. Vernon, R.L. Blake, Academic Medicine, 68, 550-563 (1993)

11. B.L. Delahaye, D.C. Limerick, G. Hearn, Adult Education Quarterly, 44, 187-200 (1994)

12. M.S. Knowles, Andragogy in action (Jossey-Bass, San Francisco, 1984)

13. R.M. Conrad, J.A. Donaldson, Engaging the online learner. Activities and resources for creative instruction (Jossey-Bass, San Francisco, 2004)

14. M.S. Knowles, E.F. Holton III, R.A. Swanson, The Adult learner: The definitive classic in adult education and human resource development (6th ed. ELSEVIER, Butterworth Heinemann, 2005)

15. A.D. Ishkov, Mezhdunarodnyy zhurnal prikladnykh I fundamental'nykh issledovaniy, 10, 122-123 (2011)

16. A.D. Ishkov, Osobennosti realizatsii dopolnitel'nogo professional'nogo obrazovaniya $v$ issledovatel'skykh universitetakh: monografiya (MGSU, Moscow, 2011)

17. D.E. Hanna, M. Glowacki-Dudka, S. Conceicao-Runlee, 147 practical tips for teaching online groups. Essentials of web-based education (Atwood Publishing, Madison, WI, 2000)

18. R. Palloff, K. Pratt, Lessons from the cyberspace classroom: The realities of online teaching (Jossey-Bass, San Francisco, 1999)

19. A.D. Ishkov, N.G. Miloradova, A.G. Chernyavskaya, Psikhologo-pedagogicheskaya podgotovka prepodavateley $v$ vysshey tekhnicheskoy shkole: realizatsiya kompetentnostnogo podkhoda: uchebnik (Arkhitektura-S, Moscow, 2011)

20. V.E. Bochkov, G.A. Krasnova, V.M. Filippov, Sostoyanie, tendentsii, problemy i rol' distantsionnogo obucheniya $v$ transgranichnom obrazovanii: uchebnoe posobi (RUDN, Moscow, 2008)

21. J. Brooks, M. Brooks, In search of understanding: the case for constructivist classrooms (Association for Supervision and Curriculum Development, Alexandria, 1993)

22. J.R. Savery, The Interdisciplinary Journal of Problem-Based Learning, 1, 9-20 (2006)

23. E.A. Savina, Izvestiya Volgogradskogo gosudarstvennogo pedagogicheskogo universiteta, 10(85), 32-36 (2013)

24. E.V. Romanova, Vestnik MGSU, 6, 532-535 (2011)

25. G.J. Conti, Principles of adult learning scale (PALS). Information on: http://www.conti-creations.com/PALS-Articles_Packet.pdf

26. A. Ishkov, T. Magera, Procedia Engineering, 117, 148-153 (2015) Information on: http://dx.doi.org/10.1016/j.proeng.2015.08.251 